\begin{tabular}{|l|l|l|l|l|l|}
\hline J. Tek. Ling & Vol. 12 & No. 1 & Hal. 85 - 92 & Jakarta, Januari 2011 & ISSN 1441-318X \\
\hline
\end{tabular}

\title{
OVEN DESTILATOR PENGOLAH SAMPAH PLASTIK RAMAH LINGKUNGAN "Pemanfaatan Asap Cair Hasil Olahan Oven Destilator untuk Pengawetan Kayu"
}

\author{
Sri Puji Ganefati, Lilik Hendrarini, dan Sarjito Eko Windarso \\ Politeknik Kesehatan, Kementerian Kesehatan, Yogyakarta
}

\begin{abstract}
Up to now, the majority of people treat plastic waste by burning and disposing it directly to the surrounding environment. The burning of the waste causes air pollution due to toxic compound called dioxin which is harmful for human health. Meanwhile, the dumping of plastic waste into water bodies can causing some negative effects such as the clogging of water duct or river which may lead to flooding. Annually, the number of plastic bag used can reach 500 million - 1 billion, which is equal to 10 fold wrapping of earth surface (Nitizen, 2008). The best handling of plastic waste are using reuse or recycle methods which are environmentally friendly and at the same time can gain economical value ${ }^{1)}$. The study is aimed to: 1) understand the capability of oven distillator in processing plastic waste into plastic grain and liquid smoke, 2) understand the influence of liquid smoke towards wood durability, 3) understand the price of the oven distillator and the corresponding break even point (BEP). The study was an experimental one and employed pre test and post test with control group design, and simultaneously assessing equipment's production capacity. The data was analyzed descriptively and analytically with Anova test and t-test at 95\% level of significance.

The results show that oven distillator capable for processing $97,3 \%$ of plastic waste into plastic grain, while the rest was converted into liquid smoke. The liquid smoke was proved affect wood preservation (anova test, $p<0.001$ ), and have similar quality compared with varnish use (t-test, $p=0,764)$. The cost analysis shows that the distillator raise economical value of the waste by $217,66 \%$, and The BEP would be reached in 68 days if $12 \mathrm{~kg}$ plastic is processed daily. It is advised that he oven can be used by general community or home industries for applying green and high economically value of plastic waste processing.
\end{abstract}

Keywords: oven distillator, plastic waste, plastic grain, liquid smoke.

\section{PENDAHULUAN}

\subsection{Latar Belakang}

Sampah merupakan bahan buangan yang harus ditangani dengan baik agar tidak menimbulkan permasalahan bagi kesehatan lingkungan dan kesehatan masyarakat. Sampah plastik merupakan salah satu jenis sampah anorganik yang sangat sulit dikelola, sehingga perlu penanganan secara khusus untuk mengurangi dampak negatif yang 
ditimbulkannya.

Salah satu dampak adanya sampah plastik yang dapat kita rasakan saat ini adalah penyebab terjadinya banjir. Kondisi ini sebagai akibat dari perilaku masyarakat dalam membuang sampah plastik tidak pada tempatnya ${ }^{2}$. Sampai sat ini, penanganan sampah plastik di masyarakat secara umum dilakukan dengan cara pembakaran dan pembuangan. Pembakaran sampah plastik menyebabkan terjadinya pencemaran udara oleh adanya gas beracun yang disebut dioksin. Pembuangan sampah plastik dapat mencemari lingkungan dan menurunkan kualitas lingkungan, yang pada akhirnya juga bedampak terhadap penurunan kunjungan wisata ${ }^{3)}$.

Menurut Nitizen ${ }^{4}$, pembuangan kantong plastik secara sembarangan mengakibatkan penyumbatan saluran air dan tanggul, yang pada akhirnya dapat mengakibatkan terjadinya banjir, bahkan dapat merusak turbin PLTA. Diperkirakan penggunaan kantong plastik di dunia dalam setiap tahunnya antara 500 juta -1 miliar kantong plastik. Apabila kantong plastik ini dibentangkan dapat membungkus permukaan bumi hingga 10 kali lipat.

Lebih dari 17 (tujuh belas) miliar kantong plastik dibagikan secara gratis oleh pedagang, baik di pasar, toko, maupun supermarket. Pada proses produksi hingga pembuangannya sampah plastik menghasilkan gas emisi ke atmosfer yang mengakibatkan efek rumah kaca, sehingga menyebabkan perubahan iklim.

Menurut Sutidja ${ }^{5}$ semua sampah yang ada mempunyai nilai ekonomi bagi manusia. Kenyataan di tempat pembuangan akhir sampah (TPA) dapat kita lihat bahwa setiap kedatangan truk sampah selalu dinantikan oleh para pemulung, karena di dalam sampah terdapat barang yang berharga yang bermanfaat bagi kehidupan keluarganya, termasuk sampah plastik. Gunawan ${ }^{1)}$, menyampaikan bahwa mendaur ulang sampah merupakan salah satu alternatif yang sangat baik dalam menangani sampah. Meningkatnya jumlah sampah plastik di masyarakat mengakibatkan penurunan kualitas lingkungan yang harus segera dilakukan penanganan dengan penemuan model yang tepat dan ramah lingkungan ${ }^{6)}$.

Sebagai salah satu upaya untuk menangani sampah plastik di atas, peneliti mencoba membuat model pengolah plastik yang ramah lingkungan dengan sistem pemanasan dan destilasi dengan produksi butiran plastik dan asap cair yang disebut Oven Distilator. Tujuan dalam penelitian ini adalah: (1). mengetahui tingkat kemampuan Oven Destilator dalam mengolah sampah plastik menjadi butir plastik dan asap cair; (2). mengetahui pengaruh penggunaan asap cair hasil olahan Oven Destilator terhadap keawetan kayu. Pengujian keawetan kayu dalam penelitian ini dibandingkan dengan vernis;. (3). mengetahui hasil taksiran harga butir plastik dan asap cair, serta BEP Oven Distilator.

\subsection{Landasan Teori}

Plastik merupakan salah satu jenis polimer sintetik yang bersifat mudah melembek bila dipanaskan dan mudah mengeras bila didinginkan. Jenis polimer ini tidak bisa diuraikan oleh mikroorganisme, dan peruraian/pelapukan plastik memerlukan waktu puluan tahun hingga ratusan tahun ${ }^{7}$. Dampak negatif adanya sampah plastik sangat besar pada kesehatan manusia dan pencemaran lingkungan.

Penimbunan plastik pada lingkungan dapat mengakibatkan gangguan kesehatan, menurunkan kualitas lingkungan, menurunkan kualitas estetika dan menghambat jalannya pembangunan. Proses produksi plastik menghasilkan gas emisi ke atmosfer bumi yang mengakibatkan efek rumah kaca. Pembakaran plastik menghasilkan bahan gas beracun yaitu gasdioksin yang apabila terhirup manusia dapat mengakibatkan 
terjadinya penyakit seperti : pemicu timbulnya kanker, hepatitis dan gangguan syaraf. Daur ulang sampah plastik dapat dilakukan dengan proses pemanasan yang ramah lingkungan dengan cara mengisolasi asap agar tidak mencemari udara.

Asap cair hasil daur ulang sampah plastik mempunyai kandungan unsur-unsur yang bersifat sebagai anti jamur, anti virus dan bersifat karsinogenik, sehingga dapat digunakan sebagai pengawet pengganti formalin ${ }^{8)}$.

\section{Metode Penelitian}

\subsection{Jenis penelitian}

Experiment study dengan rancangan sebagai berikut :

1) Menguji Tingkat Kemampuan alat Oven Destilator untuk mengetahui banyaknya produksi butir plastik dan asap cair.

2) Pret test and post test with Control group desain untuk menguji kemampuan asap cair terhadap keawetan kayu dibandingkan degan vernis

\subsection{Tempat dan Waktu Penelitian}

Penelitian bertempat di Dusun Sukunan dan waktu penelitian mulai bulan Juni sampai dengan Nevember 2010

\subsection{Obyek Penelitian}

Oven Distilator sebanyak 1 unit dan sampah plastik sebanyak $4.400 \mathrm{gr}$

\subsection{Prosedur Penelitian}

Tahap I : Pembuatan dan Pengujian Oven Distilator Pengolah Sampah Plastik

1) pengumpulan sampah plastik sebanyak $4.400 \mathrm{gr}$ dan dikelompokkan menjadi 3 (tiga) bagian, masing-masik sebanyak : $1.500 \mathrm{gr}, 1.500 \mathrm{gr}$, dan $1.400 \mathrm{gr}$.

2) Dilakukan pemasangan selang air pada Oven Distilator dan air dialirkan

3) Masing-masing kelompok sampah plastik dilakukan pengolahan menggunakan Oven Distilator selama 1 jam

4) Dilakukan penampungan butir plastik dan asap cair

5) Dilakukan penaksiran harga sampah plastik, butir plastik dan asap cair

6) Dilakukan penaksiran jumlah bahan pemakaian bakar dan tenaga

\section{Tahap II : Pengujian Pengaruh Asap} Cair terhadap Keawetan Kayu

1) Dilakukan pemotongan balok kayu sebayak 45 batang, masig-masing dengan panjang $30 \mathrm{~cm}$.

2) Dilakukan pembuatan kotak kayu didalamnya dilapisi allumunium dengan ukuran $50 \mathrm{~cm} \times 100 \mathrm{~cm}$

3) Dilakukan pencarian koloni rayap

4) Kayu dikelompokkan menjadi 3 (tiga), masing-masing sejumlah 15 batang

5) Kayu kelompok 1 diolesi asap cair dan diberi kode E1 (E1.1 sampai dengan E1.15)

6) Kayu kelompok 2 diolesi vernis dan diberi kode E2 (E2.1 sampai dengan E2.15)

7) Kayu kelompok 3 tanpa diolesi apapun dan diberi kode $\mathrm{K}$ (K.1 sampai dengan K.15).

8) Semua kayu dilakukan penjemuran selama 1 hari

9) Dilakukan penimbangan berat kayu awal (data pre test)

10) Kayu ditanam dalam koloni rayap selama 1 bulan

11) Kayu dilakukan pengeringan selama 1 hari, untuk mengurangi kelembaban selama ditanam dalam koloni rayap.

12) Dilakukan penimbangan berat kayu setelah (data post test) 


\subsection{Analisis Data}

\section{1) Menguji tingkat kemampuan Oven Distilator}

Analisis Deskriptif, digunakan untuk membahas kemampuan Oven Destilator dalam mengolah sampah plastik menjadi butir plastikdan asap cair, analisis biaya yang diperlukan dalam proses produksi dan perhitungan BEP Oven Destilator.

\section{2) Menguji pengaruh asap cair terhadap keawetan kayu}

\section{a. Analisis diskriptif}

Secara diskriptif dilakukan untuk mengetahui pengaruh asap cair terhadap pengawetan kayu dibandingkan dengan vernis dilihat dari data yang ada tabel.

\section{b. Analisis analitik}

Secara analitik dilakukan uji normalitas data dengan hasil secara berurutan sebagai berikut: $p=0.235 ; p=0.706 ;$ dan $p=0.794$ ( $p \geq \alpha=0,05$ ) atau data normal, sehingga dilanjutkan dengan Anova dan T-test dengan tingkat kemaknaan $95 \%(\alpha=0,05)$, untuk membahas pengaruh asap cair sebagai pengawet kayu.

\section{Hasil dan Pembahasan}

\subsection{Kemampuan Oven Destilator Mengolah Sampah Plastik}

Hasil pengukuran bahan baku dan hasil produksi pengolahan sampah plastik menggunakan Oven destilator disampaikan dalam tabel 1.

Dari tabel 1 dapat disampaikan bahwa pengolahan 1466,67gr sampah plastik menghasilkan butir plastik rata-rata sebanyak 1426,67 gr (97,3\% sampah plastik) dan asap cair rata-rata sebanyak $250,00 \mathrm{ml}$. Hal ini menunjukkan bahwa dengan proses produksi secara tertutup (pengovenan), hampir semua sampah plastik dapat terolah, dan hanya sebagian kecil ang menjadi asap cair (2,03\%). Proses pemanasan sampah plastik maupun proses pembuatan asap cair terjadi secara tertutup, sehingga tidak ada asap yang terbuang ke udara. Pembakaran sampah plastik secara terbuka akan menghasilkan cemaran beracun yang disebut dioksin ${ }^{4}$. Senyawa dioksin sangat berbahaya bila terhirup oleh manusia, dapat menyebabkan terjadinya berbagai penyakit antara lain: pemicu timbulnya kanker, hepatitis, pembengkakan hati dan gangguan sistem syaraf. Proses pengolahan sampah plastik menggunakan Oven Destilator, tidak menimbulkan cemaran asap. Asap yang timbul mengalami proses pendinginan sehingga berubah dari fase gas menjadi fase cair.

Berdasarkan hasil pengamatan pelaksanaan pengolahan sampah plastik menggunakan Oven Destilator, tidak ada asap yang keluar dari alat, kondisi ini dimungkinkan semua asap yang ada telah terjadi proses pendinginan dan menjadi asap cair, dapat dikatakan bahwa Oven Distilatormerupakan alat pengolah sampah plastik yang ramah lingkungan.

Tabel 1 . Hasil Pengolahan Menggunakan Oven Destilator

\begin{tabular}{|c|r|r|r|r|r|}
\hline Nomor & \multicolumn{2}{|c|}{ Bahan Baku } & \multicolumn{3}{c|}{ Hasil Produksi } \\
\hline & \multicolumn{2}{|c|}{ Sampah Plastik } & \multicolumn{2}{c|}{ Butir Plastik } & \multicolumn{1}{c|}{ Asap Cair } \\
\hline & $\mathrm{Gr}$ & $\%$ & $\mathrm{Gr}$ & $\%$ & $\mathrm{ml}$ \\
\hline 1 & 1.500 & 100 & 1.455 & 97,0 & 255 \\
\hline 2 & 1.500 & 100 & 1.456 & 97,1 & 255 \\
\hline 3 & 1.400 & 100 & 1.369 & 97,8 & 240 \\
\hline Jumlah & 4.400 & - & 4.280 & - & 750 \\
\hline Rerata & $1.466,67$ & 100 & $1.426,67$ & 97,3 & 250,00 \\
\hline
\end{tabular}


Manfaat lain penggunaan Oven Destilator dalam pengolahan sampah plastik dapat meminimalkan dampak negatif yang timbul oleh adanya penggunaan sampah plastik, serta mendapatkan hasil yang san

\subsection{Pengaruh Asap Cair terhadap Keawetan Kayu}

Asap cair berpengaruh terhadap keawetan kayu, khususnya daya tahan terhadap rayap. Kondisi disebabkan dalam asap cair plastik terdapat bahan yang bersifat racun. Bahan tersebut yaitu hidrokarbonpolicyklin aromatik, minyak dan senyawa dioksin. Senyawa hidrokarbonolcyklin aromatik mengakibatkan bau yang sangat menyengat sebagai zat yang dapat menolak keberadaan rayap, sehingga rayap tidak mau memakan kayu. Minyak yang ada dalam asap cair plastik juga dapat berfungsi untuk mengusir rayap, salah satu sifat rayap adalah tidak menyukai adanya minyak, sebagai contoh lain rayap tidak suka dengan kayu yang diolesi oli yang mengandung minyak. Seyawa dioksin yang ada dalam asap cair plastik bersifat racun bagi makluk hidup, sehingga juga tidak disukai rayap.

Penelitian ini dikuatkan oleh hasil pemeriksaan asap cair kayu yang juga dapat digunakan untuk mengawetkan kayu khususnya daya tahan terhadap rayap. Asap cair kayu mengandung berbagai senyawa yang dapat digunakan sebagai anti jamur, anti virus dan senyawa yang bersifat racun, sehingga manfaat asap cair kayu salah satunya dapat digunakan sebagai bahan pengawet kayu anti rayap ${ }^{4}$.

Secara diskriptif asap cair dapat mengawetkan kayu lebih baik bila dibandingkan dengan vernis, hal ini dapat dilihat dari besarnya kayu yang dimakan rayap kelompok asap cair lebih kecil dibandingkan dengan kelompok vernis (Tabel 2).

Tabel 2. Hasil Pengujian Pengaruh Asap Cair terhadap Keawetan Kayu

\begin{tabular}{|r|r|r|r|r|r|r|r|r|r|}
\hline No & \multicolumn{3}{|c|}{ Berat Awal } & \multicolumn{3}{|c|}{ Berat Akhir } & \multicolumn{3}{|c|}{ Selisih Berat } \\
\hline & E1 & \multicolumn{1}{|c|}{ E2 } & \multicolumn{1}{c|}{ K } & E1 & E2 & \multicolumn{1}{c|}{ K } & E1 & \multicolumn{1}{c|}{ E2 } & \multicolumn{1}{c|}{ K } \\
\hline 1 & 65 & 70 & 80 & 60 & 65 & 60 & 5 & 5 & 20 \\
\hline 2 & 80 & 42 & 40 & 77 & 40 & 30 & 3 & 2 & 10 \\
\hline 3 & 100 & 82 & 90 & 98 & 80 & 70 & 2 & 2 & 20 \\
\hline 4 & 90 & 95 & 80 & 85 & 90 & 70 & 5 & 5 & 10 \\
\hline 5 & 90 & 73 & 90 & 88 & 70 & 80 & 2 & 3 & 10 \\
\hline 6 & 75 & 93 & 83 & 70 & 90 & 60 & 5 & 3 & 23 \\
\hline 7 & 70 & 62 & 90 & 67 & 60 & 82 & 3 & 2 & 8 \\
\hline 8 & 85 & 73 & 100 & 80 & 70 & 70 & 5 & 3 & 30 \\
\hline 9 & 110 & 93 & 90 & 108 & 90 & 70 & 2 & 3 & 20 \\
\hline 10 & 80 & 75 & 70 & 79 & 70 & 44 & 1 & 5 & 26 \\
\hline 11 & 80 & 105 & 83 & 76 & 100 & 50 & 4 & 5 & 33 \\
\hline 12 & 105 & 63 & 92 & 103 & 60 & 70 & 2 & 3 & 22 \\
\hline 13 & 100 & 65 & 100 & 96 & 60 & 90 & 4 & 6 & 10 \\
\hline 14 & 80 & 90 & 85 & 77 & 83 & 70 & 3 & 7 & 15 \\
\hline 15 & 70 & 92 & 83 & 69 & 90 & 70 & 1 & 2 & 13 \\
\hline$\Sigma$ & 1210 & 1146 & 1256 & 1159 & 1120 & 976 & 47 & 55 & 270 \\
\hline $\mathrm{Rtt}$ & 80,67 & 76,40 & 83,73 & 77,27 & 74,67 & 65,07 & 3,13 & 3,67 & 18 \\
\hline
\end{tabular}


Tabel 2 menunjukkan bahwa rata-rata berat kayu yang dimakan rayap setelah satu bulan dalam koloni rayap untuk Kelompok E1, E2, K secara berurutan adalah 3,13 gr; 3,67gr; dan18,00 gr. Rata-rata terbesar berat kayu yang dimakan rayap terjadi pada kelompok Kontrol (K), sedangkan rata-rata terendah berat kayu yang dimakan rayap terjadi pada kelompok kayu yang diolesi asap cair (E1). asap cair tercampur secara homogin. Tujuan penggojogan dimaksudkan untuk mencapur semua unsur yang ada dalam asap cair, sehingga mempuanyai kualitas yang sama.

Penggunaan asap cair plastik disamping untuk pengawet kayu, juga pada prosen pengolesan tidak merubah warna dan tekstur kayu. Kayu masih dalam bentuk dan warna yang sama, sehingga bila diinginkan masih dapat diubah sesuai dengan selera.

Tabel 3. Hasil Uji Anova dan LSD

\begin{tabular}{|l|l|l|l|}
\hline No & \multicolumn{1}{|c|}{ Uji } & \multicolumn{1}{|c|}{$\mathrm{P}$} & \multicolumn{1}{c|}{ Keterangan } \\
\hline 1 & Anova & 0.000 & $0.000 \leq 0.050$, ada perbedaan bermakna \\
\hline 2 & T-Test: K dengan E1 & 0.000 & $0.000 \leq 0.050$, ada perbedaan bermakna \\
\hline 3 & T-Test: K dengan E2 & 0.000 & $0.000 \leq 0.050$, ada perbedaan bermakna \\
\hline 4 & T-Test: E1 dengan E2 & 0.764 & $0.764 \geq 0.050$, tidak ada perbedaan \\
\hline
\end{tabular}

Secara analitik, hasil uji statistik menunjukkan bahwa kualitas asap cair dalam mengawetkan kayu tidak ada perbedaan bila dibandingkan dengan vernis. Keadaan ini dimungkinkan adanya perbedaan senyawa yang ada di dalam asap cair maupun vernis. Asap cair dengan bau yang sangat menyengat, sedangkan vernis tidak terlalu menyengat, sehingga rayap kurang menyukai aroma yang ditimbulkan oleh asap air.

Penggunaan asap cair plastik pada pengawetan kayu dapat dilakukan dengan cara mengoleskan atau merendam kayu dalam asap cair plastik, kemudian dilakukan penjemuran. Proses pengawetan kayu asap cair harus dilakukan penggojogan agar lapisan minyak yang ada di permukaan
Bila dibandingkan dengan penggunaan pengawet kayu vernis, kayu yang diawetkan dengan vernis akan berubah warna dan bila dipegang terasa lengket.

\subsection{Analisis Biaya}

Dari Tabel 4. dapat diketahui bahwa taksiran harga bahan baku (sampah plastik) rata-rata sebesar Rp. 290,33,- menghasilkan butir plastik seharga rata-rata sebesar Rp. 3.567,- dan asap cair rata-rata sebesar Rp. 5.250,-. Biaya produksi mengolah sampah plastik meggunakan Oven Destilator terdiri dari biaya bahan baku, bahan bakar dan tenaga, sebesar Rp 3498,36,-. Keuntungan yang diperoleh dalam mengolah $1.466,7 \mathrm{gr}$

Tabel 4. Hasil Perhitungan Taksiran Harga Pengolahan Sampah Plastik

\begin{tabular}{|l|r|r|r|}
\hline No & \multicolumn{3}{|c|}{ Taksiran Harga (Rp) } \\
\hline 1 & Bahan Baku & $3.638,-$ & $6.375,-$ \\
\hline 2 & $300,-$ & $3.640,-$ & $6.375,-$ \\
\hline 3 & $300,-$ & $3.424,-$ & $6.000,-$ \\
\hline Jumlah & $280,-$ & $10.701,-$ & $18.750,-$ \\
\hline Rerata & $880,-$ & $3.567,-$ & $6.250,-$ \\
\hline
\end{tabular}


sampah plastik menggunakan Oven Destilator dapat diuraikan sebagai berikut.

Keuntungan $=$ (taksiran harga butir plastik + taksiran harga Asap Cair) - Biaya Produksi

$=(3.567,-+6.250,-)$ $-3.498,36,-$

$=\operatorname{Rp~9.17,--~Rp~3.498,36,-~}$ $=\operatorname{Rp} 6.318,64,-$

Jadi keuntungan yang diperoleh dalam mengolah $1466,67 \mathrm{gr}$ sampah plastik menggunakan Oven Destilator sebesar Rp 6318,64,-. Pengolahan sampah plastik dengan Oven Destilator dapat meningkatkan nilai ekonomi sampah plastik sebesar $217,66 \%$.

Pembuatan alat Oven Destilator dalam penelitian ini juga dilakukan perhitungan Break Even Point (BEP), untuk meprediksi waktu kembalinya biaya investasi. Proses pengolahan menggunakan Oven Destilator dalam mengolah sampah plastik sebanyak 1466,67gr, memerlukan waktu 1 jam, jika dalam setiap hari beroperasi selama 8 jam, maka akan mengolah sampah plastik sebanyak $11.733,36 \mathrm{gr}$ (12kg pembulatan), sehingga dapat dihitung BEP sebagai berikut :

\section{Keuntungan per hari}

$=\quad$ (keuntungan per jam $\mathrm{x}$ berat sampah perhari) : berat sampah perjam

$=(\operatorname{Rp~6.318,64,-~x~} 12 \mathrm{~kg}): 1,46667 \mathrm{~kg}$

$=\operatorname{Rp~75.823,68,-:~1,46667}$

$=$ Rp. $51.697,85,-$

\section{BEP Oven Destilator}

$=$ Harga OD : Keuntungan per hari

$=$ Rp. 3.500.000,- : Rp 51.697,87/hari

$=\quad 67,7$ hari (pembulatan 68 hari)

Jadi BEP Oven Destilator bila secara rutin untuk mengolah sampah plastik sebanyak $12 \mathrm{~kg} /$ hari akan tercapai selama 68 hari.

\section{Kesimpulan dan Saran}

\subsection{Kesimpulan}

1. Oven Destilator mempunyai tingkat kemampuan mengolah sampah plstik sebanyak $97,3 \%$ menjadi butir plastik dan 2,7\% menjadi asap cair.

2. Ada pengaruh penggunaan asap cair terhadap keawetan kayu

3. Secara diskriptif asap cair mempunyai kualitas lebih baik dalam mengawetkan kayu bila dibanding dengan vernis.

4. Taksiran harga Pengolahan sampah plastik menggunakan Oven Destilator mempunyai nilai ekonomi lebih $(217,88 \%)$.

5. BEP Oven Destilator akan tercapai dalam waktu 68 hari, bila mengolah sampah plastik sebanyak $12 \mathrm{~kg}$ dalam setiap harinya.

\subsection{Saran}

1. Bagi Badan Lingkungan Hidup, sebagai bahan masukkan dalam menangani sampah plastik yang ramah lingkungan Oven Destilator

2. Bagi masyarakat:

1) Melakukan pengolahan sampah plastik menggunakan Oven Distilator menjadi butir plastik dan asap cair

2) Menggunakan asap cair untuk pengawetan kayu agar tahan terhadap rayap dengan cara mengoleskan atau merendam.

3) Oven Destilator dapat digunakan untuk mengembangkan industri kecil.

3. Bagi peneliti lain : dapat melanjutkan penelitian untuk melihat lama dosis asap cair sampah plastik terhadap daya tahan kayu terhadap rayap

\section{Daftar Pustaka}

1. Gunawan dan Gugun, 2007, Mengolah 
Sampah Menjadi uang; Trans Media Pustaka; Jakarta.

2. Iswanto, 2000, Sistem pengelolaan Sampah Produktif Berbasis masyarakat Poltekkes Depkes Yogyakarta, Yogyakarta

3. Departemen Kehutanan R.I., 2007, Dampak Negatis Limbah sampah terhadap Lingkungan dan Pemanfaatannya, (http://www.dephut. go.id)

4. Nitizen, 2008, Bahaya Sampah Plastik bagi Lingkungan dan Kesehatan (http:// myhealthylife.wordpress.com) diunduh tanggal 29 september 2010

5. Sutidja, Trim, 2001; Daur Ulang Sampah; Bumi Aksara; Jakarta
6. Maclin dan Boy, 2009, Pengolahan limbah plastik dengan metode daur ulang/recycle, (http://onlinebuku. com/2009/01/20/pengolahan-limbahplastik-dengan-metode-daur-ulangrecycle) diunduh tanggal 29 September 2010

7. Ratna, dkk., 2010, Sifat Polimer, Kegunaan dan Dampak Polimer terhadap Lingkungan (http://www. chem-is-try.org)

8. Prananta, 2009, Asap Cair Tempurung Kelapa dan Cangkang Sawit Sebagai Alternatif Pengawet Pengganti Foormalin, diunduh tanggal 26 November 2010, dari (http://www. scribd.condoc4142857Asap-Cair) 